\title{
Interactive comment on "Spatiotemporal history of fluid-fault interaction in the Hurricane fault zone, western USA" by Jace M. Koger and Dennis L. Newell
}

\section{Matthew Steele-MacInnis (Referee)}

steelema@ualberta.ca

Received and published: 21 June 2020

I read the paper by Koger and Newell with interest. In my opinion, the motivation is clearly articulated, the data appear robust, and the interpretations seem sound. I recommend publication with only minor revisions.

Main comment:

My only real "main" comment is related to the origin of the saline brine. Around lines 320-326, the authors suggest that the brine originated as meteoric water, which circulated deep and acquired a high solute load. Perhaps. But there seem to be other 
possibilities, and I'm not sure why they are not discussed. If the source of the salinity is thought to be marine sediments, then why shouldn't we consider paleo-seawaterderived brine as a possibility? In many cases, halogen compositions of basinal brines show evidence of salinity acquired by partial evaporation of seawater. I'm not saying this is the case here; just that it could be permissible, as far as I can tell. The authors may wish to check the papers by Bruce Yardley on this subject, and may also wish to expand the discussion of where these brines may have originated. Or, if other lines of evidence argue against something like this, then please explain that here?

And related to this previous point, a couple smaller comments:

1) The salinity of $\sim 11 \mathrm{wt} \% \mathrm{NaCl}$ is on the low end for basinal brines. This might actually be an (equivocal) argument in favor of the brine representing original meteoric water that has picked up some solutes, though I would be wary of over-interpreting this. Basinal brines generally show salinities from $\sim 5$ to $>30 \mathrm{wt} \%$, and our large dataset from MVT deposits shows a prominent mode around 20 wt\% (Bodnar et al., 2014, TOG). 11 wt\% is certainly permissible for a basinal brine, just it might be worth noting that such brines can be more saline, and this may even suggest that the true basinal "end member" has not been sampled here.

2) Basinal brines are commonly enriched in $\mathrm{Ca}$, which gives rise to first-melting temperatures around $-50^{\circ} \mathrm{C}$. Was first melting truly never observed in this study? That is a bit unfortunate, though I guess "it is what it is." Still, I would ask you to revisit your notebooks and have a look for any notes you may have made about first melting, even if only for a few inclusions. Also, calcic brines commonly show a characteristic "orange peel" texture when frozen (Schlegel et al., 2012). Was anything like this observed?

These two latter comments are obviously little things, not crucial, but might help bolster your arguments about the brine and fluid mixing.

Printer-friendly version

Detailed comments: 


\section{L11: constrains}

Around L170: I suggest adding a sentence or two explaining that stretching of the fluid inclusions should have no effect on the measured Tm,ice, because stretching does not modify the composition. BUT, if the inclusions underwent any degree of leakage, then this would render the observed melting T's uninterpretable (owing to unknown degrees of $\mathrm{H} 2 \mathrm{O}$ loss, which previous studies have shown to occur preferentially when inclusions partially leak). Hence, I assume that you did careful petrographic examination to confirm that there was no evidence of partial leakage. This should probably be stated.

L220: A very minor comment, but it is awkward phrasing to say that "Secondary minerals include primarily..." I suggest to re-word

L261: I do not understand this sentence: "Where present, single-phase fluid inclusion aperture is $<15 \mu \mathrm{m}$." Please rephrase and clarify.

L265: "are generally inferred as $<50^{\circ} \mathrm{C}$ " - This is a bit misleading. Nucleation of vapor bubbles in high-density inclusions definitely depends on inclusion size (smaller inclusions are more likely to be monophase), and even inclusions with nominal Th as high as $\sim 150^{\circ} \mathrm{C}$ sometimes fail to nucleate bubbles. The relationship with inclusion size should be noted here, and I would shy away from setting a rigid threshold at $50^{\circ} \mathrm{C}$.

I would delete Eq2 and the sentence that precedes it. Just say that salinity was calculated using the equation of Bodnar '93.

L305: are used to estimate (not "are used to estimates of")

Around line 315: This is nice - the crux of the paper.

Around line 325: See my "main" comment above.

L327: Personally, I would use the term "meteoric water," instead of "meteoric groundwater." Simply because the term "groundwater" is sometimes used interchangeably with basinal or connate water. I'm not advocating for that (I find that even more confusing),
Printer-friendly version

Discussion paper 
but just for clarity and to avoid confusion, why not "meteoric water?"

Around line 425: Don't your fluid inclusion observations provide an additional argument against a role of $\mathrm{CO} 2$ degassing? Because of course, if $\mathrm{CO} 2$ degassing was occurring, you ought to find vapor-rich inclusions dominated by $\mathrm{CO} 2$. From what I can tell, there is no evidence of free $\mathrm{CO} 2$ in your dataset, right? Maybe worth mentioning.

Interactive

comment

Interactive comment on Solid Earth Discuss., https://doi.org/10.5194/se-2020-69, 2020. 